IRSTI 11.15.11

\author{
${ }^{1}$ Karabassova A.B, ${ }^{2}$ Aldabek N.A. \\ ${ }^{1}$ doctoral student, al-Farabi Kazakh national university, \\ Kazakhstan, Almaty, e-mail: tolkimiss@mail.ru \\ ${ }^{2}$ doctor of historical sciences, professor, al-Farabi Kazakh national university, \\ Kazakhstan, Almaty, e-mail: Nurzhamal25@mail.ru
}

\title{
CONTINUITY OF GENERATIONS AS A FACTOR IN THE FORMATION OF THE INTERNAL POLICY OF THE PEOPLE'S REPUBLIC OF CHINA
}

Nowadays, the People's Republic of China is one of the most dynamically developing countries and the second largest economy in the world. For this reason, the success of the "policy of reform and openness" that began in 1978 of the last centuries under the auspices of Deng Xiaoping and continued by subsequent generations of Chinese leaders in China still arouses the interest of the world community. The article attempts to analyze the role of the continuity of generations in China's politics as one of the most important factors in the construction of socialism with "Chinese characteristics", examines the relationship between the main concepts of China's development. Some of the results of the 19th Congress of the CPC are also analyzed.

Key words: Chinese leaders, Deng Xiaoping, Xi Jinping, "Socialism with Chinese characteristics", "Chinese dream", Chinese Communist Party.

${ }^{1}$ Карабасова А.Б., ${ }^{2}$ Алдабек Н.А.

'PhD докторанты, әл-Фараби атындағы Қазақ ұлттық университеті, Қазақстан, Алматы қ., e-mail: tolkimiss@mail.ru

${ }^{2}$ т.ғ.А., профессор, әл-Фараби атындағы Қазақ, ұлттық, университеті, Қазақ,стан, Алматы қ., е-mail: Nurzhamal25@mail.ru

Буындар сабақтастығы қытай халық республикасының ішкі саясатының қамыптасу факторы ретінде

Қазіргі уақытта Қытай Халық Республикасы қарқынды дамып келе жатқан елдердің бірі және әлемлегі екінші ірі экономика болып табылады. Осыған байланысты, өткен ғасырдың 1978 жылы Аэн Сяопиннің бастамасымен және Қытай көшбасшыларының кейінгі ұрпақтарымен жалғасқан «реформалар мен ашықтық саясатының» табысы әлемдік қоғамдастықтың қызығушылығын осы күнге дейін тудыруда. Берілген мақалада «қытайлық ерекшелігі бар» социализмді құру жолында ең маңызды факторлардың бірі ретінде Қытай саясатындағы ұрпақтар сабақтастығының рөлін талдауға талпыныс жасалған. Сонымен қатар, КҚК-нің 19-шы Құрылтайының кейбір қорытындылары талданды.

Түйін сөздер: Қытай көшбасшылары, Аэн Сяопин, Си Цзиньпин, «Қытайлық ерекшелігі бар социализм», «Қытай арманы», Қытай Коммунистік партиясы.

${ }^{1}$ Карабасова А.Б., ${ }^{2}$ А^дабек Н.А.

$\mathrm{PhD}$ докторант, Казахский национальный университет имени аль Фараби, Казахстан, г. Алматы, email: tolkimiss@mail.ru А.и.н., профессор, Казахский национальный университет имени аль Фараби, Казахстан, г. Амматы, email: Nurzhamal25@mail.ru

Преемственность поколений как фактор формирования внутренней политики китайской народной республики

В настоящее время Китайская Народная Республика является одной из самых динамично развивающихся стран и второй экономикой мира. По этой причине успех «политики реформ 
и открытости», начавшийся с 1978 года прошлого века под предводительством Аэн Сяопина и
продолжившийся дальнейшими поколениями китайских руководителей Китая, все еще вызывает
интерес мирового сообщества. В статье делается попытка проанализировать роль преемствен-
ности поколений в политике Китая как одного из важнейших факторов в построении социализма
с «китайской спецификой», исследуется взаимосвязь межАу основными концептами развития
Китая. Также анализируются некоторые итоги 19-го съезда КПК.
Ключевые слова: мидеры КНР, Аэн Сяопин, Си Цзиньпин, «Социализм с китайской спецификой», «китайская мечта», Коммунистическая партия Китая.

\section{Introduction}

Since 1978, China has experienced an extraordinary institutional change which has proven to be effective in promoting its economic growth and advancing its international status. It has achieved institutional change in a steady systematic and staged manner. This has altered its economic system substantially. Simultaneously, the structure of its political system has hardly altered. It remains a one-party state which relies heavily on the guidance of the leadership of the Communist Party for its direction. Institutional economists contend that the development of nations can only be well understood by considering the way their institutions change and evolve or fail to do so. This requires a concurrent account to be taken of their political, social and economic settings. The importance of doing this is apparent in China's case, where the government has played a very active role in the reform of China's institutions since 1978. Therefore, considerable attention in this article is given to political events that have influenced the development of China in the last 40 years.

A feature of the leadership of the PRC is the continuity of the transfer of power. During speeches and reports, as well as the adoption of important state decisions, special attention is paid to the accumulated experience of previous generations. This trend plays an extremely important role in public administration, thereby demonstrating the stability of the state and the credibility of the future government. Chinese leaders considered the lessons of history and are inclined to believe that "development with Chinese characteristics" will bring results only in the process of gradual development.

\section{Research Purposes and Objectives}

The purpose of the study is to show the continuity of power in the political life of China, to identify the relationship between the concepts of the leaders of the PRC. The object of the research is the policy pursued by the leaders of the PRC for 40 years since the start of the Chinese economic reform (改革开放).

Research Methodology

In this study, the method of qualitative analysis was used, drawing on the work of Western re- searchers of China's domestic policy over the past 40 years.

\section{Literature Review}

In this research, there were considered the works of Western and Chinese researchers on the continuity of power in the political life of China. Among them, the works of the following authors were analyzed: Sulmaan Wasif Khan "Haunted by Chaos: China's Grand Strategy from Mao Zedong to Xi Jinping", D. M. Lampton "Following the Leader: Ruling China, from Deng Xiaoping to Xi Jinping", Angang Hu, Yilong Yan, Xiao Tang "Xi Jinping's New Development Philosophy”, Angang $\mathrm{Hu}$ "Economic and Social Transformation in China: Challenges and Opportunities", E. Economy "The Third Revolution: XI Jinping and the New Chinese State" , Shao Binhong "China Under Xi Jinping: Its Economic Challenges and Foreign Policy Initiatives", K. Brown "CEO, China: The Rise of Xi Jinping", S.Tsang, H. Men "China's Strategy in the Coming Decade", Willy Wo-Lap Lam "Chinese Politics in the Hu Jintao Era: New Leaders, New Challenges", Ch. Li " Chinese Politics in the Xi Jinping Era Reassessing Collective Leadership", B. Gilley "Tiger on the Brink: Jiang Zemin and China's New Elite".

\section{Results and discussion}

The idea of the correct selection of candidates for public office has developed in China in the system of examination tests. This system has undergone a long evolution and still exists, contributing to the formation of the management elite in modern China. The first Europeans (missionaries, travelers, traders) who visited China from the sixteenth century, first paid attention to the exam system as an essential part of China's political and public life. For example, Jesuit Mateo Ricci wrote about China: "A remarkable fact that is worth noting as being different from the West is that the whole kingdom is ruled by an order of the enlightened, known among the people as philosophers. Responsibility for the orderly management of the whole country rests entirely with them and is entrusted to their care. It seemed that a state was finally found in which 
Plato's dream of philosopher-rulers was realized, moreover, a comparison of Western and Eastern ideal states was evident in favor of the latter $(\mathrm{Ch}$. Li, 2016: 289-290)

F. Fukuyama in his work "Confucianism and democracy", examining areas where Confucianism does not contradict democracy, singled out the traditional Confucian system of examinations for the selection of candidates for positions in the state apparatus. Even though in ancient China, this system was not truly open, in its current form, as Fukuyama notes, the examination system becomes a pass for entering higher education and state bureaucracy, thus becoming an important tool for social mobility. In other areas where Confucian and democratic principles do not contradict each other, he calls attention to education, the high level of which is an important pillar of democratic development, as well as the relative tolerance of Confucianism, which allows society to be receptive to innovations (Fukuyama F., 1995: 20-33).

The mechanism of successive transfer of power is a political institution. Institutionalized processes of continuity and the transfer of power in the PRC were the results of the development of norms and practices in the past and present.

A person who plans to become the head of China goes through a long process of informal preparation. Leaders who, in the future, want to be appointed to the highest posts in the country, must first become delegates to the CCP Congress. The preparation of candidates for leadership takes decades. In order to increase their knowledge and give deep managerial experience; they are appointed to various administrative posts throughout the country. The most promising applicants serve in several provincial offices before being promoted to the Central Government in Beijing. In addition, the advancement of a candidate on the authority line depends on his ability to make the necessary connections, in addition to creating an impressive portfolio.

During training, the candidate must not only develop his administrative skills but also create a support group within the party that will help him realize yourself as a future leader.

The last step before entering the highest position is serving in the Standing Committee of the Politburo - the most powerful power structure in PRC. To govern a big country like China, a national leader must have local and central government experience. While serving in the Politburo, the future leader is trained under the current chairman.

Also, an important point in the preparatory process is the coverage of the future leader in the media, in order to strengthen his legitimacy in public eyes both inside the country and outside of it, which quite fits into the PRC foreign policy strategy (S.Tsang, H. Men, 2015: 120-121).

The principles of collective leadership were invented by Deng Xiaoping, when the Chinese Communist Party, barely recovering from the upheavals of Maoism and the cultural revolution, decided to prevent the possibility of the emergence of a strong leader who alone could bring another disaster to the country. Then Dan decided to concentrate the levers of governing China within the framework of the Standing Committee of the Politburo of the CPC Central Committee (PSC of the CPC Central Committee), dividing power between its members.

Institutionalized transfer of power, collective decision-making, separation of duties and authority both at the PSC level and along the entire vertical of Chinese power are the three pillars of collective leadership. As a result, during the life of Deng Xiaoping, Jiang Zemin was appointed his successor, and $\mathrm{Hu}$ Jintao became the next in line to the chair of the PRC Chairman. This is how the case law emerged to appoint leaders of the next generation of leaders (隔代 指定 人) and train them in the Politburo before taking up an official position.

Over time, a set of rules governing the transfer and division of power, supplemented with new instructions. For example, the rule "seven - for the post, eight - from the post” (七上八下) appeared, which did not allow members of the PSC to sit in the post after 68 years.

Since the mid-1990s, China's authorities have embraced the notion of collective leadership, a term that can be traced back to the early years of the Chinese Communist revolution. (Yang L., Yuan J., 1991: 77-88.) Deng Xiaoping, however, made the greatest contributions to the development of collective leadership in both theory and practice. (Wang Ch., 2008: 54-58) Deng was also the first to explicitly tie the concept to the role and function of the PSC. (Hu Angang, 2013: 21-24.) On December 24, 1990, Deng said to then CCP general secretary Jiang Zemin and then premier Li Peng that "the key to China's stability lies in the collective leadership of the Politburo, especially its Standing Committee." (Deng Xiaoping, 1993: 365.) According to Deng, it would be unhealthy and dangerous if a country's fate were to depend on one or two individual leaders. (Deng Xiaoping, 1993: 310-311.)

As the history of socialism with "Chinese characteristics" has brought the results of interpretation in the process of gradual development. 
As can be seen from the history of socialist modernization since the founding of new China, we have experienced at least five generations of development concepts: Mao Zedong, Deng Xiaoping and Jiang Zemin and then Hu Jintao and later. As can be seen from the strategy and development of the five generations of development concepts, each generation represents a connecting link between the preceding and the following, advancing with the times and continuously innovating and reflecting on the characteristics of China's conditions in different periods. It also reflects the different responses of leaders in different periods to the challenges of modernization and globalization. Each generation of development idea has not only experienced historical advancement and rationality, but also historical stages and limitations. (Hu Angang, Wang Ya Hua, 2005: 164-167.)

By the end of 1976, China was in a state of deep economic and socio-political crisis. The crisis was caused by Mao Zedong's great-power militarist course, the "great leap" voluntarist policy and the Maoist "cultural revolution". In recognition of the Chinese press, 1966-1976. became a "lost decade", which threw the country back, putting the national economy on the verge of collapse. (Wasif Khan S., 2018: 45-46.)

The country's economy was almost destroyed, hundreds of thousands of people were below the poverty line. The class struggle proclaimed in the days of the "cultural revolution" further aggravated the accumulated socio-political and economic contradictions. The social policy of Mao Zedong led to a split of society - a phenomenon directly opposed to the strengthening of the political and moral unity characteristic of socialist society.

The leadership that came after the death of Mao Zedong (September 9, 1976) led by the Chairman of the CPC Central Committee and the Premier of the PRC State Council Hua Guofeng, a supporter of the "cultural revolution", announced the continuation of Mao Zedong's course. The process of reshaping the Maoist leadership, which became necessary, was accompanied by a struggle of groups for dominance in the party and state apparatus. The leading position was gradually taken by the Maoist-pragmatic group headed by Deng Xiaoping, whose rehabilitation took place in June 1977 at the III plenum of the tenth convocation of the CPC Central Committee. Deng Xiaoping was reinstated in all posts - ViceChairman of the Central Committee CPC, Deputy Chairman of the Military Council and the Chief of General Staff of the PLA, Deputy Premier of the State Council of China. The post of Chairman of the
CPC Central Committee was taken by Hua Guofeng. However, in the late 70s, Deng Xiaoping became the leader of the party and the country.

The basis for the practical development of the reform ideas of Deng Xiaoping was approved in the mid-70s, the course of the "four modernization", which was aimed at transforming in four areas - agriculture, industry, the army, science and technology. The policy of the "four modernizations" reflected the material content of the reform. The essence of the ideological and political line was represented by "four basic principles": the socialist path of development, the democratic dictatorship of the people, the leadership of the Communist Party, Marxism-Leninism, and the ideas of Mao Zedong.

At the III plenum of the CPC Central Committee of the eleventh convocation, held from December 18 to 22, 1978, on the initiative of Deng Xiaoping and his associates, a historic decision was made to abandon the theory of "continuing the revolution under the dictatorship of the proletariat" and the political goal of conducting the "class struggle", and the center of gravity of party work to transfer to the implementation of modernization. According to this, a new policy of "reforms and openness" of the PRC was announced and approved. (D. M. Lampton, 2014: 18-19.)

Thus, the main tools for the implementation of modernization were declared reforms and the policy of "openness". The reforms were aimed at bringing production relations in line with the objectives of the development of productive forces so that production relations did not become an inhibiting factor for the development of the country. And the policy of "openness" was intended to include China in the process of globalization of the economy and other spheres of life of the human community, to actively attract foreign capital, use the achievements of science and technology, management experience, in order, ultimately, to increase China's global competitiveness. "The present world is a world of broad intercourse," said Deng Xiaoping in 1984, "China was backward in the past precisely because of its isolation. After the formation of the People's Republic of China, we were blocked, but to a certain extent we kept ourselves closed ... The experience gained in more than 30 years shows that it is impossible to conduct construction behind closed doors - you cannot achieve development." Along with developing market relations, the "openness" of the country is the most important component of the new economic policy of the leaders of the CPC. Understanding the solid connection of China's modernization opportunities with its "discovery", 
with its inclusion in the global processes of material and spiritual development of the whole world is a huge merit of the CCP leadership and personally Deng Xiaoping, who opposed one of the most enduring Chinese traditions (Deng Xiaoping, 1993: 259-260.) The general purpose of Deng's reforms was simply to offer the Chinese population an exit from the Maoist extra-economic control over land, capital and labour which ended in a deadlock and hence to free them from hunger and poverty by restoring individual incentives and personal wealth, known as "socialism with Chinese characteristics" and "socialist market economy."

It is an open secret that these "Chinese characteristics" were a capitalist market economy under the political rule of a communist party. In 1980 he announced that 'Modernisation is the key to all our solutions to internal and external problems [associated with Maoism]. By the end of this century, we must try our best to reach a GDP at 1,000 American Dollars per head and live a reasonably comfortable life (xiaokang - 小康).

Deng Xiaoping, using the concept of “xiaokang" - small prosperity (“小康 水平”), began to modernize the country, which implies the achievement of "a moderately prosperous level" and the construction of a "powerful state" ( Hu Angang, 2006: 96). It means that first need to provide people with vital needs: work, food, shelter, the opportunity to learn, heal, etc., and then make plans for a "brighter future". Given that in overcrowded China, there has traditionally been a sea of poverty and misery, and in lean years millions of people died from hunger, xiaokang is a very desirable goal for most Chinese, and it should be implemented according to the decision of the 17th CPC Congress (October 2007), by 2020 . In Chinese history, it was traditionally believed that the "xiaokang" period preceded the creation of the "Da Tung" society - a great unity ("大 同”). Society "Da Tong" by Confucius involves the achievement of political ideals, in which "Celestial belonged to all."

Deng Xiaoping's follower was Jiang Zemin, he put forward the idea of a "comprehensive building a moderately affluent society and acceleration of socialist modernization in the interests of transforming socialist China into a developed and powerful country." (E. Economy, 2018: 89 - 90.)

Summing up the search for a way to bring China out of underdevelopment and poverty, Jiang Zemin, taking the baton of reform after Deng Xiaoping's death, in a report at the Fifteenth Congress of the $\mathrm{CCP}$, he noted that one of the root causes of failures in the construction of socialism in the PRC until the 3rd plenum of the CPC Central Committee of the 11th convocation in 1978 consisted in the fact that the often set tasks and political attitudes "went beyond the initial stage of socialism", which is still China. At the same time, one of the root causes of the success of the reform lies in "overcoming the erroneous views and policies that overtook the initial stage", and at the same time "stopping erroneous speeches that rejected the socialist system". (Willy Wo-Lap Lam, 1999: 50-51)

"The continuation and development of Marxism-Leninism, the ideas of Mao Zedong and the theory of Deng Xiaoping" The concept of "triple representation" put forward by Jiang Zemin in 2001 was named, according to which the CPC must constantly represent:

1) the requirements for the development of advanced productive forces;

2) the progressive direction of advanced Chinese culture;

3) the fundamental interests of the widest sections of the Chinese people.

It significantly expanded the ideological and theoretical basis of the CPC, and already at the 16th CPC Congress in November 2002, it was officially announced that individuals from private entrepreneurship could be admitted to the party, since the latter, "along with other workers, are also builders of socialism with Chinese characteristics". (Jiang Zemin, 2006: 94-96.)

The leaders of the fourth generation in the face of $\mathrm{Hu}$ Jintao in 2002 put forward the concept "Harmonic society". A harmonious society is a society that provides equality and justice in the future, as well as opportunities for general access to benefits and development outcomes that stimulate maximum disclosure of abilities, ensuring decent returns and ensuring harmonious the coexistence of each of its members, the harmony in which lies in the distribution of wealth and the harmonization of interests. Same ideas Hu Jintao repeated already in 2007 at the XVII Congress of the CPC, speaking of the notion of "small society wealth. "This is a pivotal moment in economic thought $\mathrm{Hu}$ Jintao. Thus, if earlier, in economic construction, the development of the economy was considered an axiom, now the people and the development of a harmonious society are in the center of views on development.

In 2013, changes took place in the top leadership of the People's Republic of China: Li Keqiang took the place of State Council Premier, and Xi Jinping replaced Hu Jintao as Chairman of the People's Republic of China. Shortly thereafter, the concept of the "Chinese dream" was officially introduced into 
the country's political lexicon, which was gradually incorporated as an element of the national idea of China. "The great revival of the great Chinese people is the main dream of the Chinese, we call it the Chinese dream"'(A. Hu et al., 2018:25-26) - the head of the PRC himself summed up the basic idea of this concept when he first publicly voiced it at such a high level during his visit to the Path to Revival exhibition in the November 2012 year, less than 4 months before his election to the post of Chairman. Then, this concept was actively promoted along the party line after the 18th CPC Congress, and after Xi Jinping took office, the need for "rebirth", "national renewal", "individual self-improvement", as well as achievements on time have been promised to Chinese citizens "Society of the average prosperity" repeatedly emphasized in his speeches. In addition to high-profile political slogans and promises, the "Chinese dream" simultaneously serves both as a general concept pointing to the main priorities of Xi Jinping's leadership, and includes plans for the development of the PRC for the medium and long term. At the same time, this concept has taken a key place in ideological and propaganda work both inside China and abroad, acting as an element uniting the entire nation. Such complexity and multitasking, but at the same time the space and friability of the "Chinese dream", give reason to consider it on a wider scale than the concepts put forward by Xi Jinping's predecessors Jiang Zemin and Hu Jintao.

\section{Conclusion}

The 19th CPC Congress, which took place from October 18 to October 24, 2017, opened another page in modern Chinese history, the main content of which was defined as the need to solve the tasks scheduled for the country's two hundredth anniversary: the CPC centenary in 2021 and the CPR century in 2049.

The 19th CPC Congress adopted several strategic decisions, the main of which was the renewal of ideological doctrine. All the predecessors of $\mathrm{Xi}$ Jinping as party leader contributed to the ideological and theoretical platform of the CCP. But if the "ideas of Mao Zedong" and "Deng Xiaoping's theory" symbolized turning points in the development of the theory, therefore they were defined as the result of combining the basic tenets of Marxism-Leninism "with the concrete practice of the Chinese revolution" or "with the practice of modern China and features of the era ", respectively. That is the idea of the "triple representation" of the 3rd generation of leaders led by Jiang Zemin and the "scientific concept of development" of the 4th generations led by $\mathrm{Hu}$ Jintao were only a "continuation and development of MarxismLeninism, the ideas of Mao Zedong and the theory of Deng Xiaoping," but not a new page. As the peculiarity of the 19th congress of the Communist Party of China, it can be said that he was not named as successor after Xi Jinping.

The congress was a remarkable event not only for China. The central point of the PRC's development strategy announced at the congress is the concept of "socialism with Chinese characteristics in the new era". It is recognized that the "new era" will come from 2020 and will last 30 years - until 2050. The content of the "new era" of the CCP defines as the construction of a fully modernized socialist society of general welfare (total prosperity) with a high level of material, political and spiritual culture by world standards for the 100th anniversary of the founding of the PRC (1949). Due to the aggregate "national power and international influence", the People's Republic of China by this time should become one of the world leaders.

This goal is scheduled to be achieved in two stages. The first stage is from 2020 to 2035 , when it is planned to complete the construction of a society of moderate means and basically implement socialist modernization. China will achieve technological independence and will be able to become a donor of world-class innovative technologies. On this basis, it is planned to ensure a significant increase in the proportion of the population with an average income level, sharply reduce the gap in the level of development of the city, village and regions, ensure equal access to basic public services (universal pension coverage and medical care), as well as significantly reduce property separation. The Chinese "soft power" will increase in these years.

The second stage (2035-2050) should complete the socialist modernization of China, turning it, as stated in party documents, into a society of total universal prosperity, with the property stratification of the population and the gap in the level of regional development overcome.

As indicated above, institutionalized transfer of power, collective decision-making, separation of duties and authority both at the level of the Politburo Standing Committee and throughout the vertical of Chinese power are the three pillars of collective leadership.

During the reign of $\mathrm{Xi}$ Jinping, the collective leadership system has undergone radical changes. Officially, they did not refuse it: the latest documents issued by the Communist Party contain 
an unprecedented number of references to this principle. But if earlier collective leadership was intended to institutionalize relations among elites, today the whole system of collective leadership is tied to the interests of $\mathrm{Xi}$ Jinping, his political capital, connections and personal charism. (K. Brown, 2016: 126.)

As a result, the CCP has a new theoretical platform, which means that the old era, the era of Deng Xiaoping, is passing away. It is this theoretical innovation that opens broad opportunities for making changes in the economy, domestic and foreign policy, the specific content of which has yet to be determined.

One of the main features, as well as a distinctive feature of Chinese political culture, is undoubtedly the continuity of power. In order to fully understand the modern concept of the "Chinese dream", it is necessary to consider the experience of the past. The current Chinese government already has at its disposal a certain base of state regulation based on which the modern concept is being implemented. The evolution of state regulation in the most vital areas of the PRC is creating mobile and streamlined management system that is updated with current ideas and keeps pace with modern world challenges.

In the course of the implementation of the "Chinese-specific socialism" model, much is changed and corrected, but still, several key internal components remain unchanged. Namely: a strong state; leadership and systemic role of the CPC; continuity between generations of leaders in the implementation of the strategy of reform and development.

\section{References}

Cheng Li. (2016). Chinese Politics in the Xi Jinping Era Reassessing Collective Leadership. -Washington, D.C: Brookings institution press, pp. 289-290.

David M. Lampton (2014). Following the Leader Ruling China, from Deng Xiaoping to Xi Jinping. - Berkeley: University of California Press, pp. 18-19. 365.

Deng Xiaoping (1993). Deng Xiaoping wenxuan [Selected works of Deng Xiaoping], vol. 3 - Beijing: Renmin chubanshe, pp.

Deng Xiaoping (1993). Deng Xiaoping wenxuan [Selected works of Deng Xiaoping], vol. 3 - Beijing: Renmin chubanshe, pp.310-11.

Deng Xiaoping (1993). Deng Xiaoping wenxuan [Selected works of Deng Xiaoping], vol. 3 - Beijing: Renmin chubanshe, pp.259-260.

Elizabeth Economy (2018). The Third Revolution: XI Jinping and the New Chinese State. - New York: Oxford University Press, pp. 89-90.

Francis Fukuyama (1995). Confucianism and democracy. Journal of Democracy, vol. 6, No 2, pp. 20-33.

Hu Angang, Wang YaHua (2005). National Conditions and Development - Beijing: Tsinghua University Press, pp. 163-167.

Hu Angang, Zhongguo (2013). Jiti lingdao tizhi [The system of collective leadership in China] - Beijing: Zhongguo renmin daxue chubanshe, pp. 21-24.

Hu Angang, Yilong Yan, Xiao Tang. (2018). Xi Jinping's New Development Philosophy. - Singapore: Springer press, pp. 25-26.

Jiang Zemin (2006). Jiang Zemin Wenxuan[Selected works of Jiang Zemin], vol 3 - Beijing: Renmin chubanshe, pp. 94-96.

Steve Tsang, Honghua Men (eds.) (2015). China's Strategy in the Coming Decade. - Beijing: China Economics Publishers, pp. $120-121$.

Sulmaan Wasif Khan (2018). Haunted by Chaos: China's Grand Strategy from Mao Zedong to Xi Jinping. - Cambridge, Massachusetts: Harvard University Press, pp. 45-46.

Wang Chunxi, (2008). Deng Xiaoping dui jianli zhongyang jitilingdao tizhi kuangjia de gongxian. [Deng Xiaoping's contribution to the system of collective leadership of the Central Committee of the Chinese Communist Party], Dang de wenxian [Literature of the Chinese Communist Party], no. 5, pp. 54-58.

Willy Wo-Lap Lam (1999). The Era of Jiang Zemin. - New York: Prentice Hall, pp. 50-51.

Yang Liuji, Yuan Junhong (1991). Dang de jitilingdao zhidu de xingcheng yu fazhan [The formation and development of collective leadership in the Chinese Communist Party], Zhonggong dangshi yanjiu [Party History Research Center of the Central Committee of the Chinese Communist Party], No. 4, pp.77-88. 